\title{
Development of Basin Solar Still by Adding Magnetic Treatment Unit and Double Glass Cover Provided with Water
}

\author{
Asaad Rehman Saeed Al-Hilphy \\ Department of Food Sciences, Agriculture College, Basrah University, Iraq
}

Received 2013-07-14, Revised 2013-08-05; Accepted 2013-08-29

\begin{abstract}
The basin solar still was developed by adding a magnetic treatment unit, it's energy 0.12 Tesla and two layer of glass provided with water between them. The study was conducted by testing the device by using magnetic water + double glass provided with water, non magnetic water + double glass cover, magnetic water + single glass cover, non magnetic water + single glass cover and control treatment (without additions). Intensity of incidence solar radiation in Basrah province during the month of April, Temperature in the basin solar still, glass cover surface, ambient, $\mathrm{pH}$, water electric conductivity, productivity, density, physical and chemical properties were measured. Theoretical productivity and efficiency were calculated. The results showed that the average of solar radiation intensity is $889.55 \mathrm{~W} / \mathrm{m}^{2}$. Temperature of basin solar still, glass cover surface and ambient was increased with increasing solar radiation intensity. The maximum of temperature in the basin water of solar still is $56.61{ }^{\circ} \mathrm{C}$ at using magnetic water + single glass cover which has best performance compare with other treatments and having $\mathrm{pH} 7.03$, minimum electric conductivity is $0.000672 \mathrm{~S} / \mathrm{m}$ and density reached to $1000 \mathrm{~kg} / \mathrm{m}^{3}$ and gave highest efficiency at $32.55 \%$ and it's productivity improved by $50 \%$ compared with conventional.
\end{abstract}

Keywords: Solar Still, Basin, Magnetic Water

\section{INTRODUCTION}

Water is life in all it's forms. All living organisms contain water the body of a human being is composed of approximately $60 \%$ of water, a fish of $80 \%$, plant between 80 and $90 \%$. Water is necessary for the chemical reactions that occur in living cells and is also in the middle of this water that these cells are formed. Water is essential to sustainable food production as well as all living ecosystem, human development is based entirely on the hydrological cycle (Chaouachi, 2011).

Solar desalination is on of the cheapest methods for distilled water production. Solar still is widely used in the solar desalination. The yield of the single basin solar still is very less compared to that of other conventional desalination methods (Tanaka et al., 2000). Single basin solar still is a popular solar device used for converting available brackish or waste water. Because of it's lower productivity, it's not popularly used. A number of works are under taken to improve the productivity of the still. The still productivity and efficiency depend on parameters like location, solar radiation intensity, atmospheric temperature-basin water depth, glass cover material, thickness and it's inclination, wind velocity and the heat capacity of the still (Tiwari et al., 1995; 1998; Singw et al., 1995; Ghoneyem and Ileri, 1997; Tiwari and Madhuri, 1985; El-Sebaii, 2000; Yousef and Abu-Arabi, 2004; Tripathi and Tiwari, 2006).

Akash et al. (1998) and Tiwari and Tiwari (2007) were carried out to determine the still efficiency, the efficiency was ranged from 15-25\%. Moreover, a parameter study was performed Al-Hinai et al. (2002) on a conventional double-sloped single basin solar still under climate conditions of the sultanate of Oman at the Gulf region, this study showed that under optimum design condition, the still trends to give an 
average annual solar yield of approximately 4 $1 / \mathrm{m}^{2}$ day. Nafey et al. (2000) stated that using black gravel of $20-30 \mathrm{~mm}$ size improve the productivity by $19 \%$ at the condition of $201 / \mathrm{m}^{2}$ brine volume and 15 glass cover angle. Also Velmurugan et al. (2008) added pebbles in the solar still and found that the productivity increased by $20 \%$ than the conventional solar still. Productivity of solar still was increased with increase of absorber area. Fins are integrated with solar still to increase the absorber plate area (Velmurugan and Srithar, 2011). The aim of the present paper is to development of basin solar still by adding magnetic treatment unit and double glass provided with water.

\section{MATERIALS AND METHODS}

A basin solar still is shown in Fig. 1, 2a, b and c was designed and manufactured in the food engineering laboratory at Basrah University. Water magnetic unit is used to producing magnetic water and double glass cover provided with water was added to the solar still. Apparatus consist of basin area of the still is $0.24 \mathrm{~m}^{2}$ manufactured using iron steel of 18 gauge thickness. The bottom and sides of the basin are insulted by $2.5 \mathrm{~cm}$ thick foam surrounded by wooden frame of $2 \mathrm{~cm}$ thickness. Trough made of aluminum which used to collecting distilled water that put in the forward the basin which have 0.25 in. diameter aluminum pipe which connected with plastic pipe to out put distilled water. The basin is containing of porosity black stones, the purpose of black stones to absorbance solar radiation and heating of basin water, as well as increasing the evaporation. Tank is made of stainless steel 314 and connected behind the solar still. Magnetic treatment unit was connected under tank that consists of two static magnets their intensity is 0.12 Tesla and the plastic pipe put between them to producing magnetic water. Using magnetic waterto producing low surface tension of waterwhich increasing of evaporation then increasing of productivity. Balance tank was setup beside of the solar still to control on water level in the basin. Aluminum foil was putted in the inner wall of basin to reflect sun rays on the water basin. Double glass cover inclined 30 degree was provided with water is put between glasses to increasing of condensation.

Solar radiation intensity was measured by Pyranometer type Kipp-Zonen Model CM11 is used for measuring solar radiation data. Through this instrument most of the available data on solar radiation are obtained. A pyranometer produces voltages from the thermopile detectors that are a function of the incident radiation. Temperatures of basin water and glass cover are measured by thermocouples type cu-constantan. Ambient temperature is measured by a thermometer. $\mathrm{pH}$ is measured according to APHA (1995). Electrical Conductivity (EC) was measured, according to Chapman and Pratt (1962).

$\mathrm{pH}$, Total Dissolved Solid (TDS) were measured by water analysis kit and manual methods. Calcium and magnesium hardness ofwater was estimated by complex ometic titration method (Prajapati and Roal, 2004). Chloride contents were determined volumetrically by silver nitrate titration method using potassium chromate as anindicator. It was calculated in terms of ppm (Mitra and Gupta, 1999).

Productivity $\left(1 / \mathrm{m}^{2}\right.$.day): the collection of output distilled water from distiller at limit time has been measured then productivity is calculated from the following Equation 1:

$P_{r}=\frac{M_{\text {out }}}{A_{g} t} \times 100$

Practical efficiency is calculated from the following Equation 2 (Tanaka et al., 2000; Badran and Abu-Khader, 2007):

$\mathrm{E}(\%)=\frac{\mathrm{M}_{\text {out }} \mathrm{h}_{\mathrm{fg}}}{\mathrm{I} \mathrm{A}_{\mathrm{g}}} \times 100$

The correlation of Latent heat of water evaporation is given by Sharma and Mullick (1993):

$\mathrm{h}_{\mathrm{fg}}=3044205.5-1679.1109 \mathrm{~T}_{\mathrm{w}}-1.14258 \mathrm{~T}_{\mathrm{w}}^{2}$

Statistical analysis: Data were analyzed using SPSS software SPSS, 2011.

Theoretical productivity and efficiency were calculated according to Sharma and Mullick (1993).

The energy used for evaporation is Equation 4 and 5:

$\frac{\mathrm{q}_{\mathrm{e}}}{\mathrm{A}_{\mathrm{g}}}=\frac{\mathrm{h}_{\mathrm{ewg}}}{\mathrm{U}_{\mathrm{i}}} \mathrm{U}_{\mathrm{t}}\left[\mathrm{T}_{\mathrm{w}}-\mathrm{T}_{\mathrm{a}}\right]$

$M=\frac{q_{e}}{f_{g h}}$ 


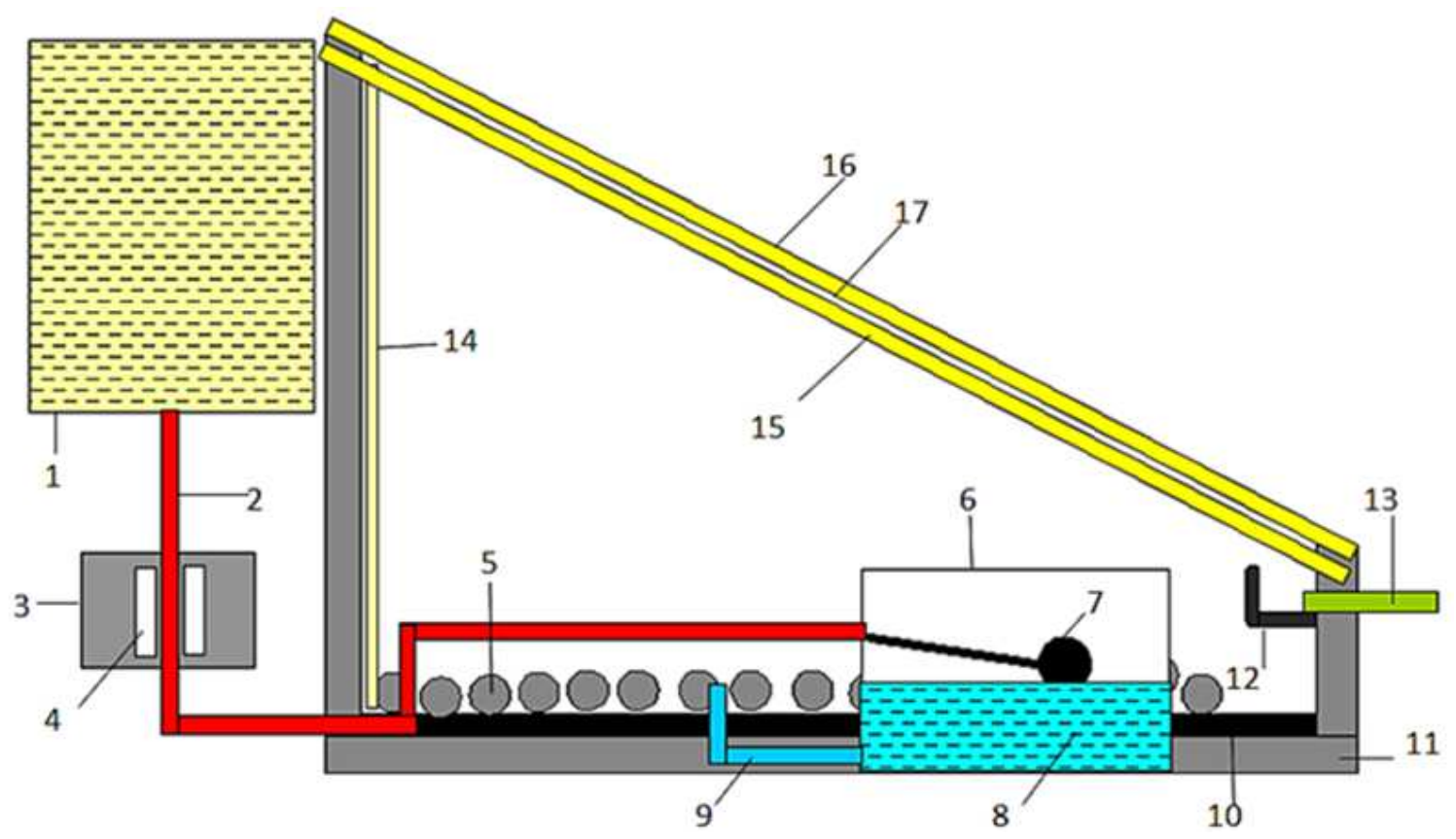

Fig. 1. Schematic diagram of basin solar still with magnetic water and double glass 1. Tank, 2. plastic pipe, 3. magnetic treatment unit, 4. Static magnet, 5. Porosity black stones, 6. Balance tank, 7. Float, 8. Basin water, 9. Plastic pipe, 10. Basin, 11. Wooden frame, 12. Trough, 13. Pipe, 14. Reflector, 15. inner glass cover, 16. Outer glass cover, 17. Water

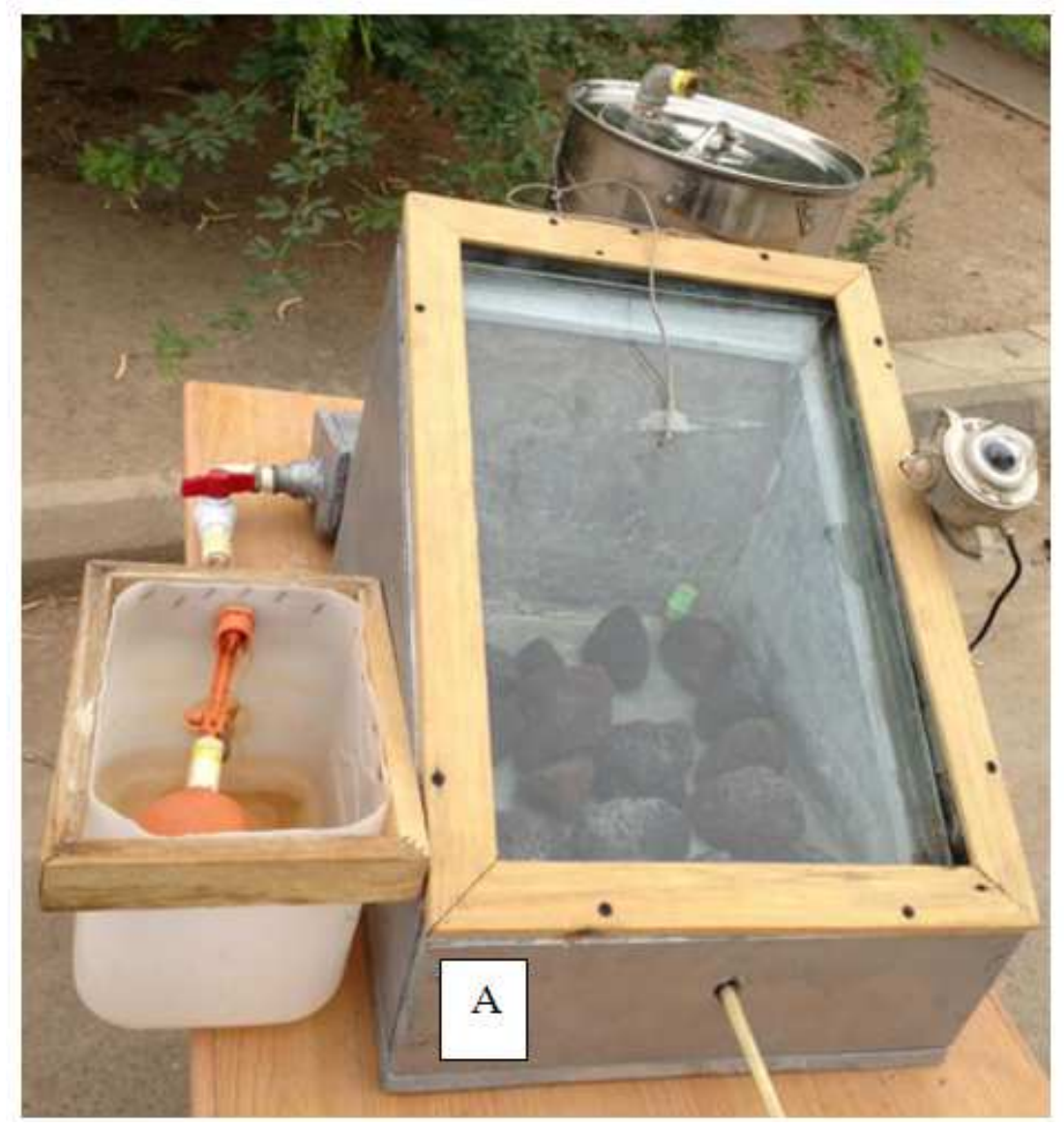



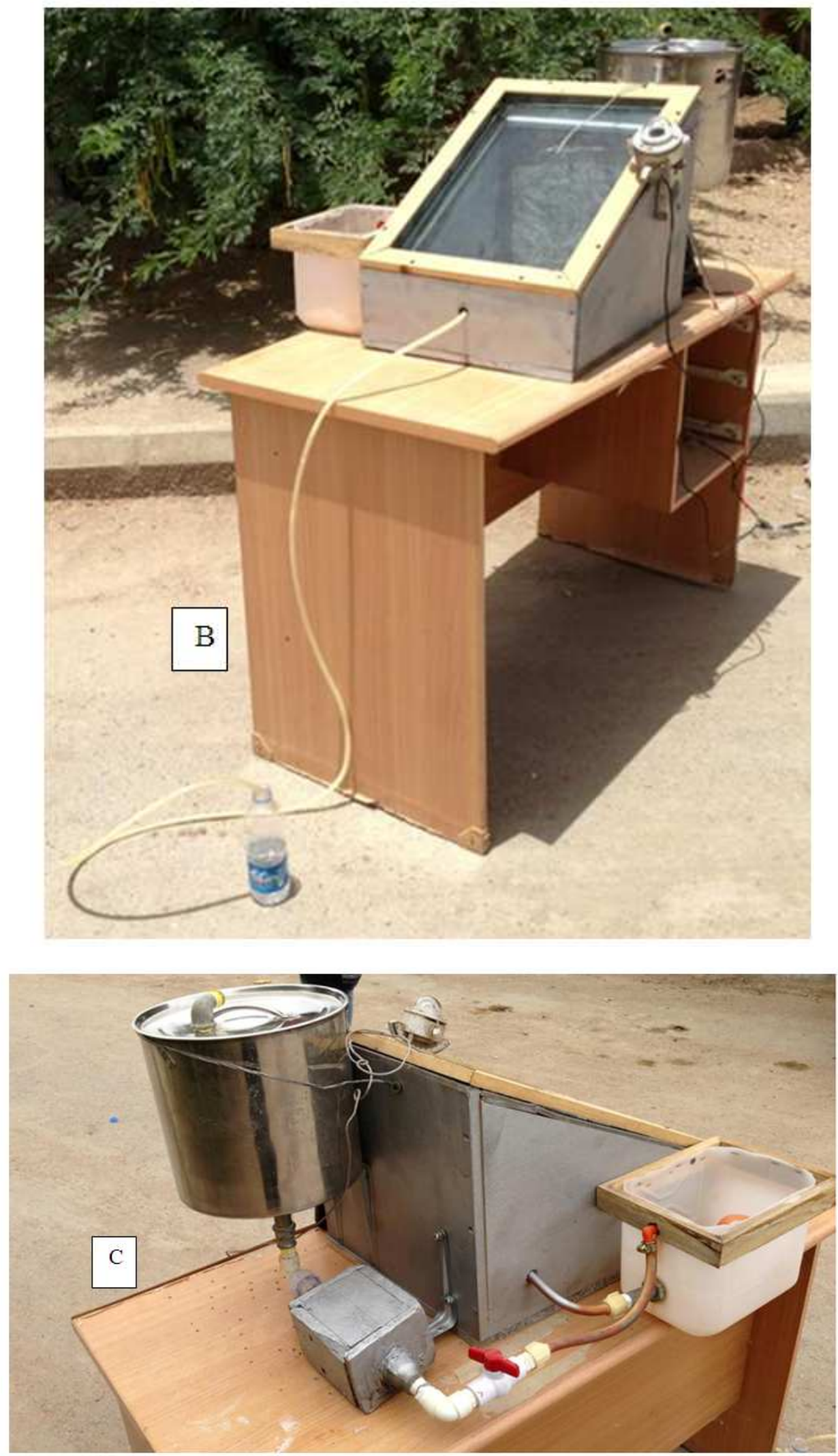

Fig. 2. Photograph of local basin solar still with magnetic treatment unit and double glass. (A) Top, (B) in front, (C) behind 
By combining Equation (3) in (4) and after integration in the daytime period we have Equation 6:

$\mathrm{M}_{\text {out(th) }}=\mathrm{A}_{\mathrm{g}} \frac{\mathrm{h}_{\mathrm{ewg}} \mathrm{U}_{\mathrm{t}}}{\mathrm{h}_{\mathrm{fg}} \mathrm{U}_{\mathrm{i}}} \Delta \mathrm{t}\left[\ddot{\mathrm{T}}_{\mathrm{wd}}-\mathrm{T}_{\mathrm{ad}}\right]$

Heat transfer coefficient in a solar still is calculated as the following equations (Sharma and Mullick, 1993).

The overall upward heat flow factor between water and environment is given by Equation 7:

$\mathrm{U}_{1}=\left[\frac{1}{\mathrm{U}_{\mathrm{i}}}+\frac{1}{\mathrm{~A}_{\mathrm{r}} \mathrm{U}_{\mathrm{o}}}\right]^{-1}$

Where Equation 8 to 10:

$\mathrm{U}_{\mathrm{i}}=\mathrm{h}_{\mathrm{cwg}}+\mathrm{h}_{\mathrm{ewg}}+\mathrm{h}_{\mathrm{rwg}}$

$\mathrm{U}_{\mathrm{o}}=\frac{\mathrm{h}_{\mathrm{w}}\left(\mathrm{T}_{\mathrm{g}}-\mathrm{T}_{\mathrm{a}}\right)}{\mathrm{T}_{\mathrm{g}}-\mathrm{T}_{\mathrm{s}}}+\mathrm{h}_{\mathrm{rgs}}$

$\mathrm{A}_{\mathrm{r}}=\frac{\mathrm{A}_{\mathrm{g}}}{\mathrm{A}_{\mathrm{w}}}$

The convective, evaporative and radiative heat transfer coefficients between water in basin and glass cover are Equation 11 to 13 :

$$
h_{c w g}=0.884\left[\left(T_{w}-T_{g}\right)+\frac{P_{w}=P_{g}}{2016-P_{w}}-T_{w}\right]^{1 / 3}
$$

)

$$
\begin{aligned}
& \mathrm{h}_{\text {ewg }}=0.88\left[\frac{9.15 \times 10^{-7} \mathrm{~h}_{\text {ewg }}\left(\mathrm{P}_{\mathrm{w}}-\mathrm{P}_{\mathrm{g}}\right) \mathrm{h}_{\mathrm{fg}}}{\left(\mathrm{T}_{\mathrm{w}}-\mathrm{T}_{\mathrm{g}}\right)}\right] \\
& \mathrm{h}_{\text {ewg }}=0.9 \sigma\left(\mathrm{T}_{\mathrm{w}}^{2}-\mathrm{T}_{\mathrm{g}}^{2}\right)\left(\mathrm{T}_{\mathrm{w}}+\mathrm{T}_{\mathrm{g}}\right)
\end{aligned}
$$

The radiative and convective heat transfer coefficients between cover and environmental are Equation 14:

$$
\mathrm{h}_{\mathrm{rgs}}=\varepsilon_{\mathrm{g}} \sigma\left(\mathrm{T}_{\mathrm{g}}^{2}-\mathrm{T}_{\mathrm{s}}^{2}\right)\left(\mathrm{T}_{\mathrm{g}}+\mathrm{T}_{\mathrm{s}}\right)
$$

The following equations can be used to calculation of the above heat transfer coefficients Equation 15:

$$
\mathrm{T}_{\mathrm{s}}=0.0552 \mathrm{~T}_{\mathrm{a}}^{1.5}
$$

Partial water vapor pressure for temperature range 10 $-150^{\circ} \mathrm{C}$ Equation 16 :

$$
\mathrm{p}=165960.72 \times 10^{-\left[\mathrm{x}\left(\mathrm{a}+\mathrm{bX}+\mathrm{cX} \mathrm{X}^{3}\right)\right] /[\mathrm{T}(1+\mathrm{dX})]}
$$

Where:
$\mathrm{X}=647.27-\mathrm{T}$
$\mathrm{A}=3.2437814$
$\mathrm{B}=5.86826 \times 10^{-3}$
$\mathrm{C}=1.1702379 \times 10^{-8}$
$\mathrm{D}=2.187852 \times 10^{-3}$

Theoretical solar radiation intensity is calculated by the Equation (17) (Lunde, 1980):

$I_{T}=I_{D N}\left(\cos \theta+c \frac{1+\cos \beta}{2}+\rho(\sin \alpha+C) \frac{(1-\cos \beta)}{2}\right)$

Theoretical efficiency is given by Equation (18):

$\mathrm{E}_{\mathrm{th}},(\%)=\frac{\mathrm{h}_{\mathrm{fg}} \mathrm{M}_{\text {out }(\mathrm{th})}}{\mathrm{I}_{\mathrm{T}} \mathrm{A}_{\mathrm{g}}} \times 100$

The theoretical efficiency can be found by using the following formula for the system with reflector (Ayav and Atagunduz, 2007) Equation 19:

$E_{\text {th }},(\%)=\frac{h_{\text {fg }} M_{\text {out(th })}}{I_{T} A_{g}+I_{s, b} \times A_{\text {she }}} \times 100$

\section{RESULTS AND DISCUSSION}

The experimental work was carried out in Basrah city-Iraq (Latitude 30³3' 56.55' N, Longitude: 4745' 5.86 "E). The theoretical and practical solar radiation intensity during day hours are shown in Fig. 3. The maximum and minimum of practical solar radiation intensity average was 1084.33 and $602.40 \mathrm{~W} / \mathrm{m}^{2}$ respectively in April in clear days. The theoretical solar radiation intensity was higher than the practical solar radiation intensity in the morning and after hour of 15.00 but the theoretical solar radiation intensity was lower than the practical solar radiation intensity at day hours from 11.30 to 15.00 . The variation between the practical and theoretical solar radiation intensity is caused by to the theoretical values was depended on the apparent extraterrestrial solar radiation, extinction coefficient and diffused solar radiation coefficient are calculated for United State American cities by meteorological stations. Conditions of these cities are differ from Basrah city conditions, these factors led to the variation between the theoretical and practical data, as well as present light dust in Basrah weather is led to reducing the solar radiation intensity in some times. These results are agreed with (Al-Hilphy, 2006; Al-Hilphy, 2010). Average practical solar radiation intensity in April 2013 is $889.55 \mathrm{~W} / \mathrm{m}^{2}$. 


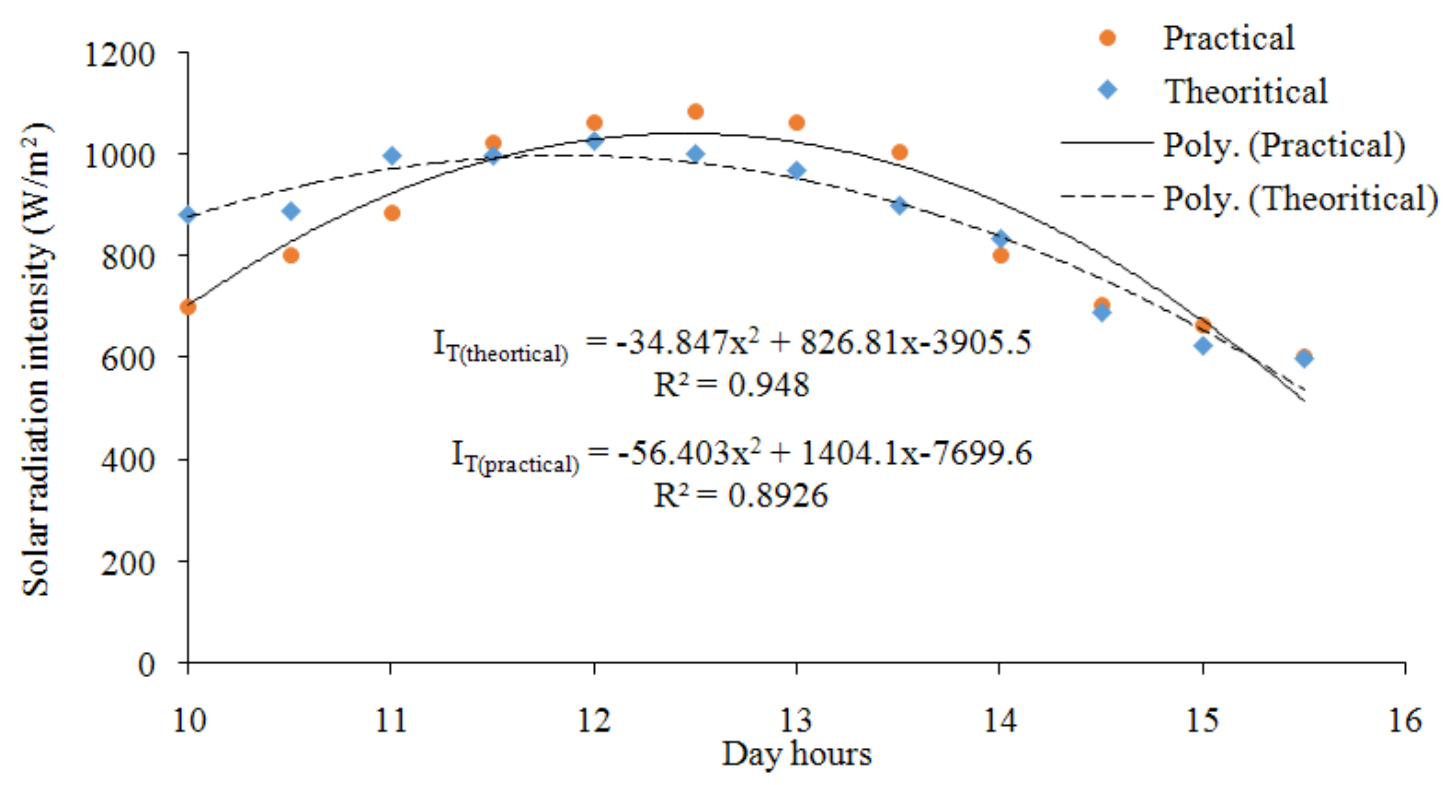

Fig. 3. Solar radiation intensity Vs. day hours in April 2013

Figures 4-7 Illustrated the change in the temperature of ambient, glass cover and basin water during day hours with and with out magnetic treatment unit and single or double glass cover. Results showed that the temperature of ambient, glass cover and basin water are increased with increasing day hours up to maximum value at 15:30 pm (except ambient temperature at $15.00 \mathrm{pm}$ ) and then it decreases at using magnetic water and double glass cover (Fig. 3). This is because increasing of solar radiation intensity with day hours at 10:00 am to $12: 00$ noon and this may be attributed to the increase of the absorbency of the solar energy entering the still by water. Also this is due to the process using mainly the thermal energy stored in the water itself. Results similar to the findings of many investigators (Delyannis and Piperoglou, 1965; Mustafa et al., 1979; Al-Hayek and Badran, 2004; Ayav and Ataguduz, 2007). The maximum temperature of basin water is $57.53,56.61,55.68$ and $42.38^{\circ} \mathrm{C}$ at using magnetic water and double glass cover, magnetic water + single glass cover, single glass cover + without magnetic water and double glass cover + without magnetic water respectively. The effect of ambient temperature variations on solar still productivity isexamined by the several researchers. The numerical results showed that a slight increaseof $3 \%$ in the solar still productivity is obtained by increasing the ambient temperatureby $5^{\circ} \mathrm{C}$ (Nafey et al., 2000).

The comparison of the daily productivity of distilled water between the conventional and modified desalination systems is shown in Fig. 8. The daily productivity of magnetic water + single glass cover treatment is higher than conventional treatment and other modified systems. The daily productivity of the solar distiller provided with magnetic water unit and single glass cover teatment was improved by increasing the evaporation and heat transfer rate of the system as magnetic water. The daily productivity is improved by $50 \%$ compared with conventional treatment as shown in Fig. 8. The differences betweenthe theoretical daily productivity, the conventional and modified desalination systems are significantly $(\mathrm{p}<0.05)$. Al-Hinai et al. $(2002)$ found the productivity of solar still approximately $4 \mathrm{l} / \mathrm{m}^{2}$.day.

The results showed in the Fig. 9. that the highest efficiency was when using magnetic water+ single glass cover and reached to $32.55 \%$ and this because the magnetized water that led to reduce the surface tension of water and increase the speed of evaporation, as indicated that Al-Hilphy (2011). The least efficient was at using a double glass cover + without magnetized water which reached to $6.51 \%$. This decrease in efficiency is caused by increasing the thickness of the cover, which led to reduce the intensity of solar radiation inside to basin water, a result of increased distilled reflections and fractures of the solar radiation. Alkan (2003) stated that using a thin glass cover to allow more solar energy to pass to saline water in the still. A good quality glass will be suitable for solar desalination application. It has low iron contents, hence low absorptivity of radiation and consequently high transmissivity. Also the results showed there is no significant differences between magnetic water + double glass cover treatment and conventional. There are significant $(p<0.05)$ differences between modified desalination systems efficiency and theoretical efficiency. 
Asaad Rehman Saeed Al-Hilphy / American Journal of Engineering and Applied Sciences 6 (3): 286-296, 2013

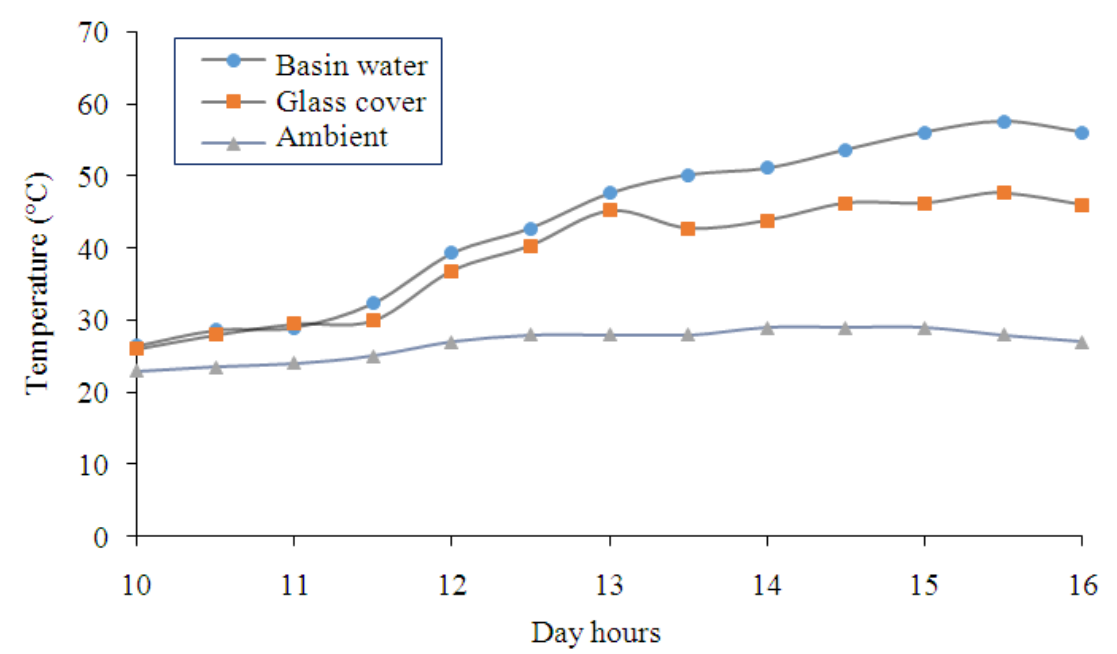

Fig. 4. Temperature of ambient, basin water and glass cover during day hours in April 2013 at using magnetic water + double glass cover

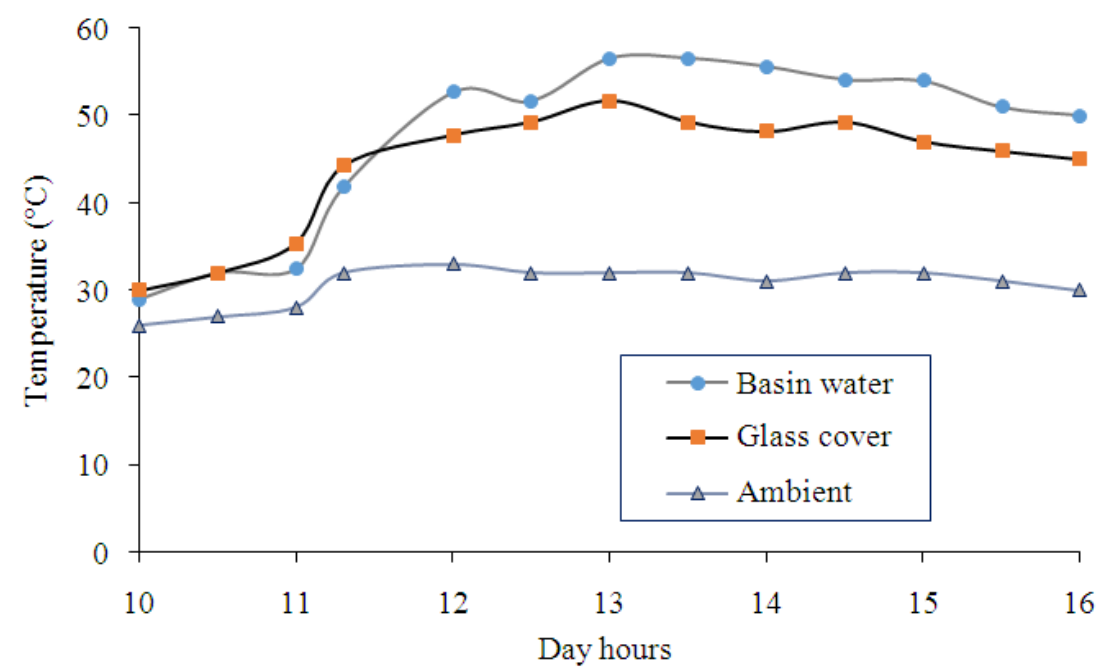

Fig. 5. Temperatureof ambient, basin water and glass cover during day hours in April 2013 at using magnetic water +single glass cover

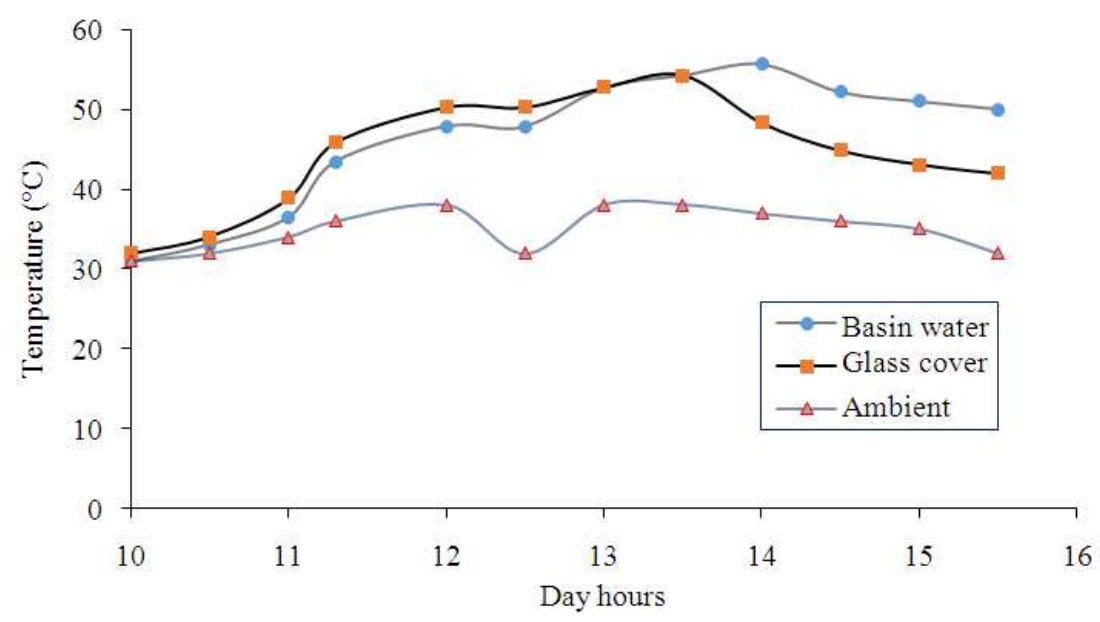

Fig. 6. Temperature of ambient, basin water and glass cover during day hours in April 2013 at using single glass cover + without magnetic water 


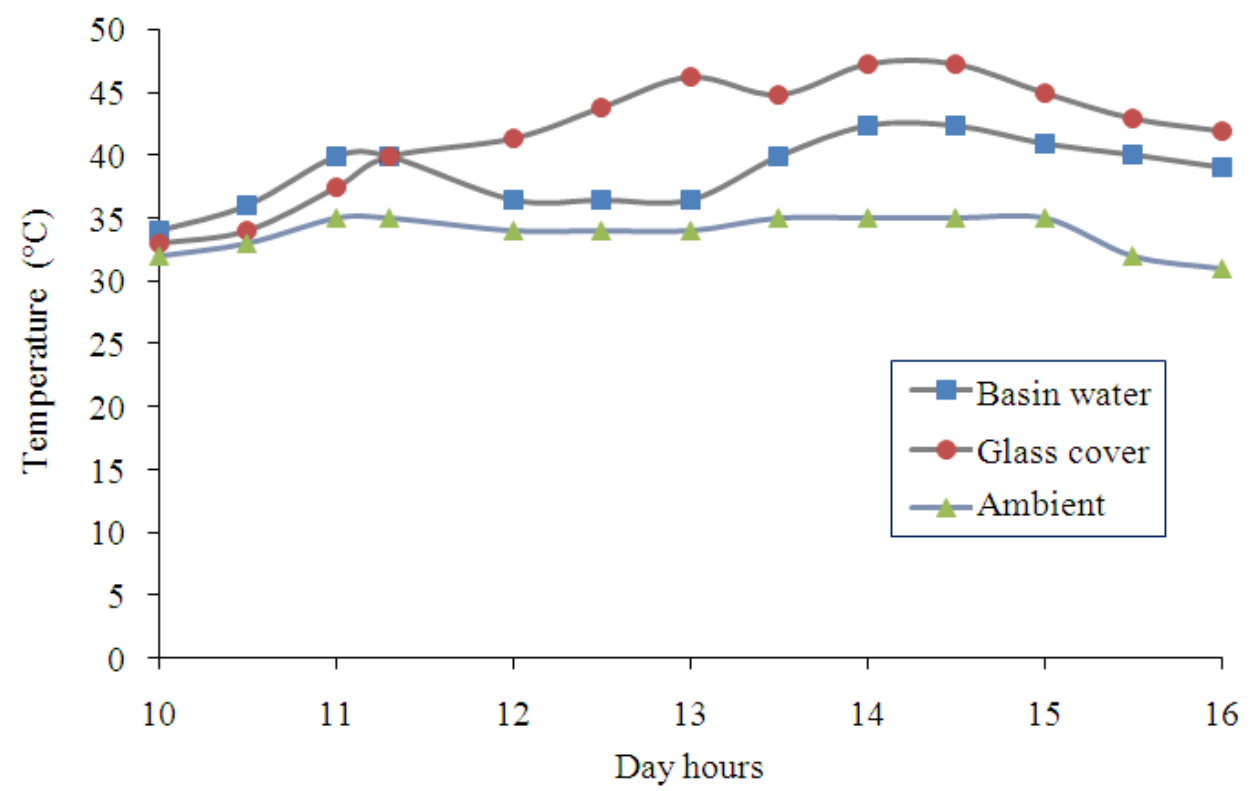

Fig. 7. Temperature of ambient, basin water and glass cover during day hours in April 2013 at using double glass cover + without magnetic water

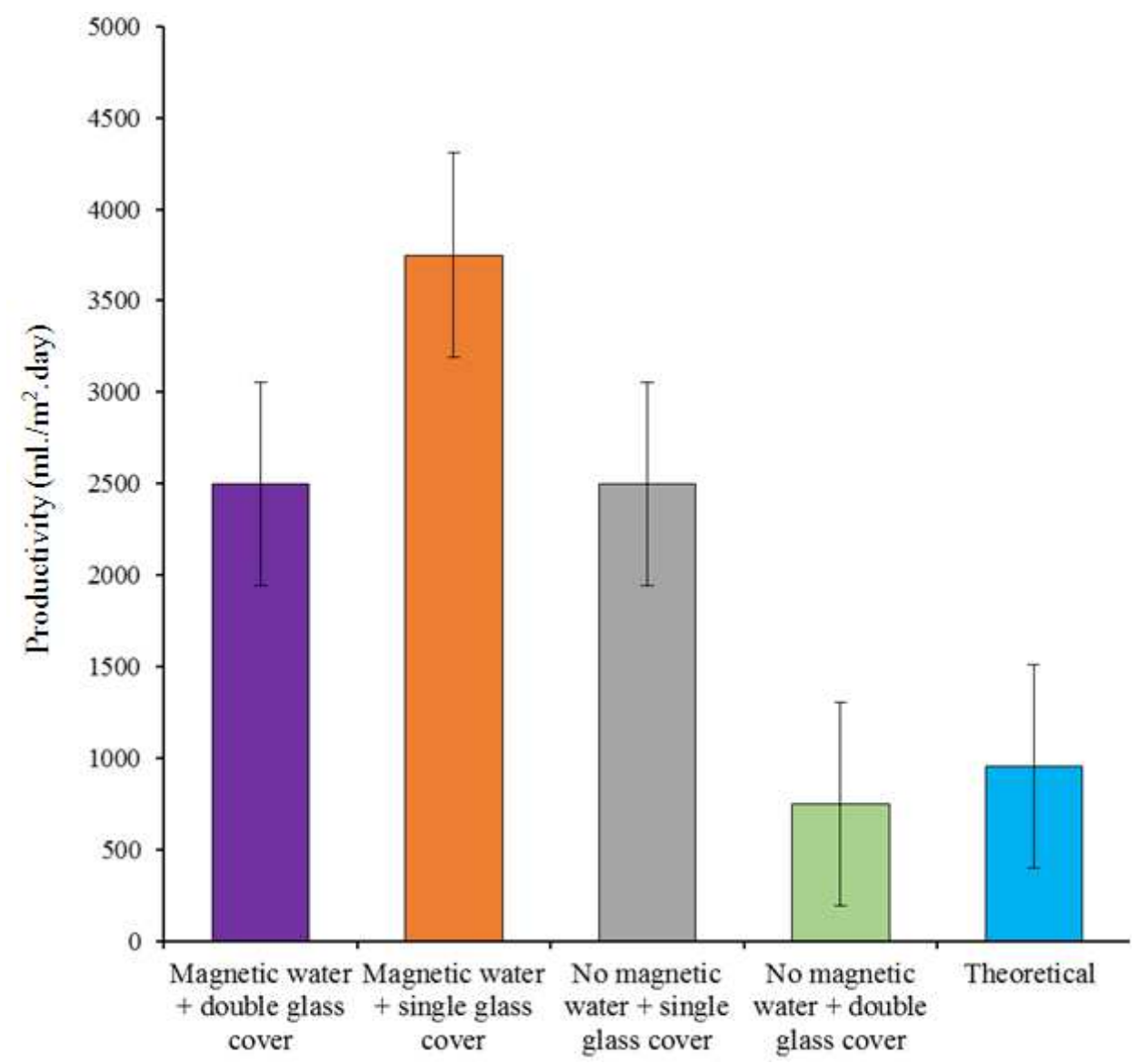

Fig. 8. Daily productivity $\left(\mathrm{ml} / \mathrm{m}^{2}\right.$ day) comparison between the conventional and modified desalination systems 


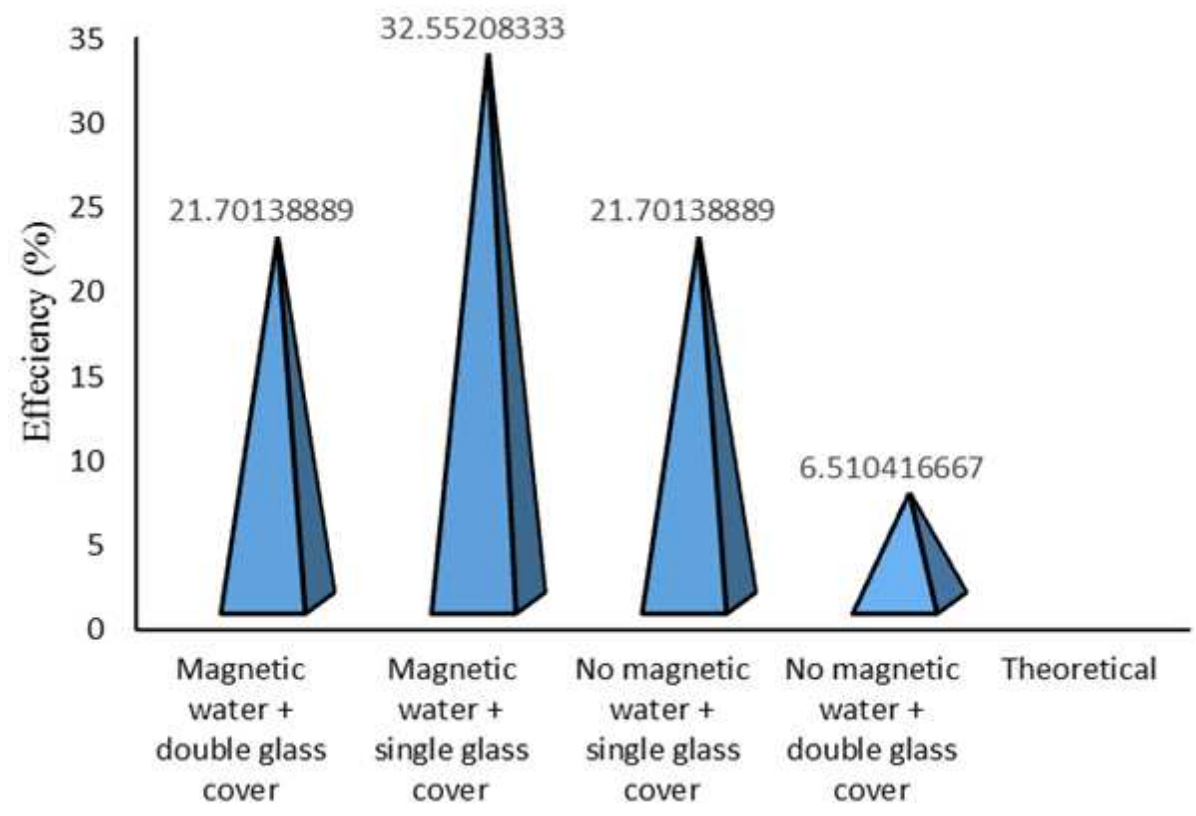

Fig. 9. Efficiency comparison between the conventional and modified desalination systems

Table 1. Physical and chemical propertiesof magnetic and non magnetic water before and after distillation

\begin{tabular}{|c|c|c|c|c|c|c|c|c|c|c|c|}
\hline $\begin{array}{l}\text { Treat- } \\
\text { ments }\end{array}$ & $\begin{array}{l}\mathrm{EC} \\
(\mathrm{S} / \mathrm{m})\end{array}$ & $\mathrm{pH}$ & $\begin{array}{l}\text { Density } \\
\left(\mathrm{kg} / \mathrm{m}^{3}\right)\end{array}$ & $\begin{array}{l}\text { TDS } \\
\text { ppm }\end{array}$ & $\begin{array}{l}\text { TSS } \\
\text { ppm }\end{array}$ & $\begin{array}{l}\text { Thr. } \\
\text { ppm }\end{array}$ & $\begin{array}{l}\mathrm{Cl}^{-} \\
\mathrm{ppm}\end{array}$ & $\begin{array}{l}\text { T.H } \\
\text { NTU }\end{array}$ & $\begin{array}{l}\mathrm{Ca}^{++} \\
\mathrm{ppm}\end{array}$ & $\begin{array}{l}\text { Alk. } \\
\text { ppm }\end{array}$ & $\begin{array}{l}\mathrm{Mg}^{++} \\
\mathrm{ppm}\end{array}$ \\
\hline $\mathrm{A}$ & $0.204000^{\mathrm{a}}$ & $7.93^{\mathrm{a}}$ & $1042^{\mathrm{a}}$ & $1340^{\mathrm{a}}$ & $15.00^{\mathrm{a}}$ & $6^{\mathrm{a}}$ & $378.00^{\mathrm{a}}$ & $537.0^{\mathrm{a}}$ & $108.0^{\mathrm{a}}$ & $139^{\mathrm{a}}$ & $65.00^{\mathrm{a}}$ \\
\hline B & $0.206000^{\mathrm{a}}$ & $7.55^{\mathrm{b}}$ & $1039^{\mathrm{a}}$ & $1345^{\mathrm{a}}$ & $10.00^{\mathrm{b}}$ & $2^{\mathrm{b}}$ & $382.00^{\mathrm{b}}$ & $548.0^{\mathrm{b}}$ & $110.0^{\mathrm{b}}$ & $145^{\mathrm{b}}$ & $66.00^{\mathrm{b}}$ \\
\hline $\mathrm{C}$ & $0.001649^{b}$ & $7.44^{\mathrm{b}}$ & $1001^{\mathrm{b}}$ & $43^{b}$ & $0.30^{\mathrm{c}}$ & $0.21^{\mathrm{c}}$ & $0.30^{\mathrm{c}}$ & $7.1^{\mathrm{c}}$ & $2.2^{\mathrm{c}}$ & $25^{\mathrm{c}}$ & $1.10^{\mathrm{c}}$ \\
\hline $\mathrm{D}$ & $0.000672^{c}$ & $7.03^{\mathrm{c}}$ & $1000^{\mathrm{b}}$ & $39^{c}$ & $0.18^{d}$ & $0.19^{d}$ & $0.19^{\mathrm{d}}$ & $6.5^{\mathrm{d}}$ & $1.2^{\mathrm{d}}$ & $20^{\mathrm{d}}$ & $0.78^{d}$ \\
\hline E & $0.001288^{b}$ & $7.06^{\mathrm{c}}$ & $1002^{b}$ & $40^{\mathrm{b}}$ & $0.26^{\mathrm{c}}$ & $0.23^{\mathrm{c}}$ & $0.27^{\mathrm{c}}$ & $7.5^{\mathrm{e}}$ & $1.9^{\mathrm{e}}$ & $24^{c}$ & $0.95^{\mathrm{e}}$ \\
\hline $\mathrm{F}$ & $0.002190^{\mathrm{b}}$ & $8.34^{\mathrm{d}}$ & $1001^{b}$ & $44^{\mathrm{d}}$ & $0.30^{\mathrm{c}}$ & $0.28^{\mathrm{e}}$ & $0.29^{c}$ & $7.9^{f}$ & $2.1^{\mathrm{c}}$ & $26^{\mathrm{e}}$ & $1.30^{\mathrm{f}}$ \\
\hline
\end{tabular}

A: No magnetic water, before distillation, B: magnetic water, before distillation, C: Magnetic water + double glass cover, D: Magnetic water + single glass cover, E: No magnetic water + single glass cover, F: No magnetic water + double glass cover

There is another aspect which needed attention was quality of desalinated water. Many parameters are important in this regard are electrical conductivity, $\mathrm{pH}$, density, Total Dissolved Solids (TDS), Total Suspended Solids (TSS), turbidity (Thr.), $\mathrm{Cl}^{-}$, Total Hardness (T.H.), $\mathrm{Ca}^{++}$, alkalinity (Alk.) and $\mathrm{mg}^{++}$. Table 1 Showed that the electrical conductivity of magnetic and non magnetic tap water in Basrah province was significantly $(p<0.05)$ higher than magnetic and non magnetic distilled water. In addition, distilled water by the distiller provided with magnetic water + single glass cover has little values of all parameters (EC, pH, Density, TDS, TSS, Thr. $\mathrm{Cl}^{-}, \mathrm{T} . \mathrm{H}$, $\mathrm{Ca}^{++}$, Alk. and $\mathrm{Mg}^{++}$) compared with other treatments. This is due to a little thickness of glass which permission to passing of solar radiation into basin water that increased of evaporation rate. In the other handthe magnetic water led to increasing of evaporation. These results agreed with Samee et al. (2007), who stated that higher values of conductivity indicate presence of more dissolved solids and hence more salinity. The acceptable range of $\mathrm{pH}$ for drinking water is between 6.5 to 8.5 . $\mathrm{pH}$ measures water acidity or alkalinity. Levels below 6.5 may be corrosive, while levels above 8.5 may create scaling problems and a bitter taste (AHS, 2011). Increasing the magnetic flux density caused water clearness, in addition to a relative increase in the $\mathrm{pH}$ value and a remarkable decrease in its odor and Electric Conductivity (EC) (Alkhazan and Saddiq, 2010). The recommended limit of TDS, Thr. $\mathrm{Cl}^{-}$, T.H, Alk. and $\mathrm{Mg}^{++}$in drinking water are less than $500 \mathrm{mg}$ $\mathrm{L}^{-1}$ (WHO, 1994; 2004), less than 1 NUT (EAS, 1999), less than $250 \mathrm{mg} \mathrm{L}^{-1}$, between 80 and $100 \mathrm{mg} \mathrm{L}^{-1}$, between 80 and $100 \mathrm{mg} \mathrm{L}^{-1}$ and $150 \mathrm{mg} \mathrm{L}^{-1}$ (AHS, 2011) respectively.

\section{CONCLUSION}

A basin solar still was fabricated and tested. The optimized modified desalination system wasmagnetic water + single glass cover. The efficiency was calculated as $32.55 \%$ which is comparable with stills being worldwide. The productivity of the basin solar still is augmentedby adding magnetic water + single glass coverand improved by 
$50 \%$ compared with conventional treatment. Also it is found that quality of distilled water using magnetic water + single glass cover is better than other treatments.

\section{Nomenclature}

$A_{g} \quad$ transparent cover area $\left(\mathrm{m}^{2}\right)$.

$A_{r} \quad$ ratio of $\mathrm{A}_{\mathrm{g}} / \mathrm{A}_{\mathrm{w}}$

$A_{w} \quad$ black surface basin area $\left(\mathrm{m}^{2}\right)$.

$A_{\text {she }} \quad$ Effective shaded area on the glass cover

C Constant

E Practical efficiency (\%).

$\mathrm{E}_{\text {th }} \quad$ Theoretical efficiency (\%).

$h_{\text {ewg }} \quad$ evaporative heat transfer coefficient between water and glass cover $\left(\mathrm{W} / \mathrm{m}^{2} \mathrm{~K}\right)$.

$h_{r w g}$ radiative heat transfer coefficient between glass cover and water $\left(\mathrm{W} / \mathrm{m}^{2} \mathrm{~K}\right)$.

$h_{\text {rgs }}$ radiative heat transfer coefficient between glass cover to sky $\left(\mathrm{W} / \mathrm{m}^{2} \mathrm{~K}\right)$.

$h_{c w g} \quad$ convective heat transfer coefficient between water and glass cover $\left(\mathrm{W} / \mathrm{m}^{2} \mathrm{~K}\right)$

$h_{f g} \quad$ Latent heat of vaporization $(\mathrm{J} / \mathrm{kg})$.

$h_{w} \quad$ wind heat transfer coefficient $\left(\mathrm{W} / \mathrm{m}^{2} \mathrm{~K}\right)$.

I Practical solar radiation intensity $\left(\mathrm{W} / \mathrm{m}^{2}\right)$.

$I_{s . b} \quad$ Beam reflected for the reflector $\left(\mathrm{W} / \mathrm{m}^{2}\right)$

$\mathrm{I}_{\mathrm{DN}} \quad$ Direct normal irradiation $\left(\mathrm{W} / \mathrm{m}^{2}\right)$.

$I_{T} \quad$ theoretical solar radiation intensity $\left(\mathrm{W} / \mathrm{m}^{2}\right)$.

$M_{\text {out }} \quad$ daily produced distillate $(\mathrm{kg})$.

$M_{\text {out }(t h)} \quad$ Theoretical daily produced distillate $(\mathrm{kg})$.

$q_{e} \quad$ Evaporation heat transfer rate (W).

$p_{w} \quad$ partial vapour pressure to water $(\mathrm{mmHg})$

$p_{g} \quad$ partial vapour pressure to glass cover $(\mathrm{mmHg})$

$P_{r} \quad$ Productivity $\left(1 / \mathrm{m}^{2}\right.$.day)

$T \quad$ Thermodynamic temperature $(\mathrm{K})$.

$T_{a} \quad$ ambient temperature (K).

$T_{\text {sky }} \quad$ sky temperature (K).

$T_{g} \quad$ glass temperature $(\mathrm{K})$

$T_{w} \quad$ water temperature $(\mathrm{K})$

$U_{o} \quad$ heat transfer coefficient between glass cover environment $\left(\mathrm{W} / \mathrm{m}^{2} \mathrm{~K}\right)$.

$\Delta t \quad$ duration of the day (sec.).

$U_{i} \quad$ heat transfer coefficient between water and glass $\left(\mathrm{W} / \mathrm{m}^{2} \mathrm{~K}\right)$.

$U_{t} \quad$ overall upward heat flow factor between water and environment $\left(\mathrm{W} / \mathrm{m}^{2} \mathrm{~K}\right)$.

wind speed $(\mathrm{m} / \mathrm{s})$

About 0.2

Incident angle (deg.).

Inclination angle of glass cover (deg.)

Sun altitude

About 0.2

\section{REFERENCES}

AHS, 2011. Interpretation of Chemical Analysis of Drinking WaterRecommendedLevels.
Akash, B., M. Mohsen and O.Y. Osta, 1998. Elayan, Experimental evaluation of a single-basin solar still using different absorbing materials. Renew. Energy, 14: 307-310. DOI: 10.1016/S0960-1481(98)00082-2

Al-Hayek, I. and O.O. Badran, 2004. The effect of using different designs of solar stills onwater distillation. Desalination, 169: 121-127.

Al-Hilphy, A.R.S., 2006. Development of solar dryer and study it's efficiency in drying of some fruits and vegetable. PhD Thesis, Agric. College, Basrah Univ. Basrah, Iraq, pp: 171.

Al-Hilphy, A.R.S., 2011. Magnetic water and it's effect on the food and consumer health. Scientific Bulletin, 1. Food Science dept., Agric. College, Basrah University, Iraq. pp: 12.

Al-Hilphya, A.R.S., 2010. Food Engineering by solar Energy. 1st Edn., Alzehra Press. Basrah, Iraq. pp: 364.

Al-Hinai, H., M.S. Al-Nassri and B.A. Jubran, 2002. Effect of climatic, design and operational parameters on the yield of a simple solar still. Energy Convers. Manage., 43: 1639-1650. DOI: 10.1016/S0196-8904(01)00120-0

Alkan, P.I., 2003. Theoretical and Experimental Investigations on Solar Distillation of IYTE Gülbahçe Campus Area Seawater.Msc. Thesis, İzmir Institute of Technologyİzmir, Turkey, pp: 129.

Alkhazan, M.M.K. and A.A.N. Saddiq, 2010. The effect of magnetic field on the physical, chemical and microbiological properties of the lake water in Saudi Arabia. J. Evolutionary Biol. Res., 2: 7-14.

APHA, 1995. Standard methods for the examination of water and waste water. Washington USA.

Ayav, P.I. and G. Atagunduz, 2007. Theoretical and experimental investigation on solar distillation of IZTECH campus area seawater. Desalination, 208: 169-180.

Badran, O.O. and M.M. Abu-Khader, 2007. Evaluating thermal performance of a single slope.

Chaouachi, R., 2011. Solar Desalination. In: Schoff, M. Eds., Desalination, trend and technologies. In Tech. Europe. ISBN: 978-953-307-311-8. P. 217-236.

Chapman, H.D. and P.F. Pratt, 1978. Methods of Analysis for Soils Plants and Waters. Univ. of California, Div. Agric. Sci. Priced Publication, pp: 4034.

Delyannis, A. and E. Piperoglou, 1965. Solar distillation in Greece.1st. Int. Symp.Water desalination. Washington. D. C.

EAS, 1999. Distillation specification. EAS 123, Rev. 1:2009, ICS pp: 71:100.

El-Sebaii, A.A, 2000. Effect of wind speed on some designs of solar stills. Energy Convers. Manage., 41: 523-538. DOI: 10.1016/S0196-8904(99)00119-3 
Ghoneyem, A.L. and A. Ileri, 1997. Software to analyze solar stills and an experimental study on the effects of the cover. Desalination, 114: 37-44. DOI: 10.1016/S0011-9164(97)00152-5

Lunde, P.J., 1980. Solar Thermal Engineering. 1st Edn., Willey, New York.

Mitra, A. and S.K. Gupta, 1999. J. Indian Soc. Soil. Sci., 47: 99-105.

Mustafa, S.M.A., G.H. Brusewitz and D.M. Farmer, 1979. Solar Energy, 22: 141. DOI: 10.1016/0038092X(79)90098-7

Nafey, A.S., M. Abdelkader, A. Abdelmotalip and A.A. Mabrouk, 2000. Parameters affecting solar still productivity. Energy Conversion Manage., 41: 1797-1809. DOI: 10.1016/S0196-8904(99)00188-0

Prajapati, J.R. and B.V. Raol, 2004. Physico-chemical bacteriological study of different brands of commercial drinkingwater samples from North Gujarat. Poll Res., 23: 165-168.

Samee, M.A., U.K. Mirza, T. Majeed and N. Ahmed, 2007. Design and performance of a simple basin solar still. Renewable Sustainable Energy Rev., 11: 543-549. DOI: 10.1016/j.rser.2005.03.003

Sharma, V.B. and S.C. Mullick, 1993. Solar Engineering. Trans. ASME, J. 155.P.231.

Singw, A.K., G.N. Tiwari, P.B. Sharma and E. Khan, 1995. Optimization of orientation for higher yield of solar still for a given location. Ener. Convers. Manage., 36: 175-187. DOI: 10.1016/01968904(94)00045-2

Tanaka, H., T. Nosoko and T. Nagata, 2000. A highly productive basintype-multiple-effect coupledsolar still. Desalination, 130: 279-93. DOI: 10.1016/S0011-9164(00)00092-8

Tiwari, A.K. and G.N. Tiwari, 2007. Thermal modeling based on solar fraction and experimental study of the annual and seasonal performance of a single slope passive solar still: The effect of water depths. Desalination, 207: 184-204. DOI: 10.1016/j.desal.2006.07.011
Tiwari, G.N., J.M. Thomas and E. Khan, 1995. Optimisation of glass cover inclination for maximum yield in a solar still, Heat Recov. Sys. CHP, 14: 447-455.

Tiwari, G.N. and H.P. Madhuri, 1985. Effect of water flow over the glass cover of a single basin solar still with an intermittent flow of waste hot water in the basin. Ener. Convers. Manage., 25: 315-322. DOI: 10.1016/0196-8904(85)90049-4

Tiwari, S., A.A. El-Sebaii and E. El-Bialy, 1998. Investigation of a single-basin solar still with deep basins. Renew. Ener., 14: 299-305. DOI: 10.1016/S0960-1481(98)00081-0

Tripathi, R. and G.N. Tiwari, 2006. Thermal modeling of passive and active solar stills for different depths of water by using the concept of solar fraction. Solar Energy, 80: 956-967. DOI: 10.1016/j.solener.2005.08.002

Velmurugan, V., C.K. Deenadayalan, H. Vinod and K. Srithar, 2008. Desalination of effluent using fin type solar still. Energy, 33: 1719-1727. DOI: 10.1016/j.energy.2008.07.001

Velmurugan, V. and K. Srithar, 2011. Performance analysis of solar stills based on various factors affecting the productivity-a review. Renewable Sustainable Energy Rev., 15: 1294-1304. DOI: 10.1016/j.rser.2010.10.012

WHO, 1994. International Standards for drinking water WHO, Geneva.

WHO, 2004. Guidelines for drinking water quality, recommendation. Vol. I. Switzerland. Geneva: World Health Organization.

Yousef, H. and M. Abu-Arabi, 2004. Modelling and performance analysis of a regenerative solar desalination unit. Applied Therm. Eng., 24: 10611072. DOI: $10.1016 /$ j.rser.2010.10.012 